\title{
SCIDoC
}

\author{
International Journal of Dentistry and Oral Science (IJDOS) \\ ISSN: 2377-8075
}

\section{Active Monitoring Of Person Exposed To Patients With Confirmed Covid - 19}

Research Article

Brundha $^{1 *}$, Vignesh $^{2}$

${ }^{1}$ Associate professor, Department of General Pathology Saveetha Dental College and Hospitals, Saveetha Institute of Medical and Technical Sciences No: 162, PH Road Chennai, TamilNadu- 600077, India.

${ }^{2}$ Department of General Pathology, Saveetha Dental College and Hospitals, Saveetha Institute of Medical and Technical Sciences, Saveetha University, Chennai -77, TamilNadu, India.

\section{Abstract}

Coronavirus disease 2019 is an illness brought about by extreme severe respiratory condition coronavirus (SARS-CoV-2). It was first determined in the 2019 December month in Wuhan fish market in China, and has brought about a progressing epidemic. The first case might be recorded back on 17 November 2019.

Symptoms of the COVID-19 include cough, fever, dyspnea, fatigue, and ability to smell and taste is lost. While a large portion of the cases show mild signs and symptoms, some of them arrive at acute respiratory distress syndrome (ARDS) likely encouraged by a cytokine storm, septic stun, multi-organ failure , and blood clumps. After exposure the time it takes to begin symptoms is generally around six days or it may go from two to fourteen days.

The virus is initially spread between person to person during close contact, most commonly by means of small droplets that come out by sneezing, talking, and coughing. The droplets usually fall onto things and not travel through air over long distances. Less ordinarily, individuals may get infected by contacting a contaminated surface at that point then touching their face. It's generally infectious toward the start of the initial three days after the beginning of indications, despite the fact that the spread is achievable before manifestations show up, and from individuals that don't show side effects.

Keywords: COVID- 19; Transmissions; Management; Global Pandemic; Prevention.

\section{Introduction}

In 1930, the first coronavirus was discovered. An acute respiratory infection of tamed Chicken was caused by injections of bronchitis Virus (IBV) [17], Anther Schalk, and M.C. Hawn described in 1931 a brand new respiratory virus of Chicken in North Dakota (Fabricant, 1998). Later, Between 1930 - 1940 three more different animal corona Viruses were Cultivated and were kept isolated, at that period they did not realize that these various different viruses were related (McIntosh, 1974). In 1960 the first human coronavirus was discovered. The isolation was done using two different methods in the United nation and in America. In 1960 same year Original research was done about Virus isolation from Common cold occurring in a residential School. From the general population the school boy was tested. Malcolm Byone, E.C. Kendall, and David Tyrrell working at the Common Cold Unit of the
British Medical Research Council in 1960 isolated from a boy a novel common cold virus B814. [26, 23] The discovered virus was not technically cultivated using normal standard methods which had successfully cultivated rhinoviruses, adenoviruses and other common cold viruses. Like this furthermore, viruses are cultivated and monitored [14] After a few decades, the coronavirus strain B814 was lost $[40,44]$.

Infected individuals are able to contaminate the environment. The interaction of the complementary cell receptor and coronavirus spike protein is central in determining the infectivity, tissue tropism and species range of the released virus. Coronavirus target epithelial cells [15]. They are transmitted from one individual to another individual depending on the corona Virus species by either aerosol fomite or orofecal route [16]. Patients infected with coronavirus Can present a wide range of signs and symptoms

\section{*Corresponding Author:}

Brundha,

Associate professor, Department of General Pathology Saveetha Dental College and Hospitals, Saveetha Institute of Medical and Technical Sciences, Chennai - TamilNadu - 600077, India.

Email Id: brundha.sdc@saveetha.com

Received: February 25, 2021

Accepted: March 04, 2021

Published: March 08, 2021

Citation: Brundha, Vignesh. Active Monitoring Of Person Exposed To Patients With Confirmed Covid - 19. Int J Dentistry Oral Sci. 2021;08(03):1921-1924. doi: http://dx.doi. org/10.19070/2377-8075-21000381

Copyright: Brundha 2021 . This is an open-access article distributed under the terms of the Creative Commons Attribution License, which permits unrestricted use, distribution and reproduction in any medium, provided the original author and source are credited. 
extending from mild to severe. cough, Fever, and dyspnea are the most common symptoms reported, and $31 \%$ of casesm [22]. Patients that develop acute respiratory distress Syndrome may worsen rapidly and die of multiple organ failure [28].

\section{Covid - 19 Outbreak}

An outbreak of viral infection of unknown origin was first determined in Wuhan fish market, Hubei, provinces, china. It was started in December 2019. There Case was epidemiologically connected to the human seafood market [2]. Inoculation of bronchoalveolar lavage liquid acquired from patients with viral infection of unknown Origin in to human airway epithelial cell and Huh7 and Vero E6 cell lines led to the isolation of a SARSCoV-2, novel coronavirus, earlier named 2019-nCov [4, 25$].$

Coronaviruses are positive single-stranded RNA viruses surrounded by an envelope belonging to the family Coronaviridae. They are classified in to four genera Alphacoronavirus, Betacoronavirus, Gammacoronavirus, and Deltacoronavirus. So far seven human coronaviruses (HCoVs) have been identified, which fall within the Alpha-and Betacoronavirus genera.

SARS-Cov are animal origin, they cause severe respiratory syndrome and are often fatal. From the beginning of the pandemic in late December 2019, SARS-COV-2 has now spread to all continents as of May 21, 2020, the world health organization. Communicated 5,101,526 Confirmed cases and 329,203 deaths globally. The name Coronavirus was coined by June Almeida and David Tyrrell (He is the one who found novel common cold B814 in a Schoolboy) [43]. Coronavirus can infect the gastrointestinal and upper respiratory tract of mammals and birds [5].

\section{Mode Of Transmission Of Covid - 19}

Respiratory infections might be transmitted through droplets of different sizes: once the droplet particle unit area is $>5-10 \mu \mathrm{m}$ in diameter they're called respiratory droplets, and once then unit area $<5 \mu \mathrm{m}$ in diameter, they're called as droplet nuclei [13]. In step with current proof, the COVID - 19 virus is principally transmitted between people through respiratory droplets and by contacting individuals $[11,28]$.

Droplet transmission happens once someone is in close contact (with in one meter) with some body who has symptoms (e.g., coughing or sneezing) and is thus in danger of getting his/her mucosae (mouth and nose) or mucous membrane (eyes) exposed to probably infective metabolism droplets [32].

Droplet transmission is entirely different from airborne transmission since it refers to the presence of microbes inside droplet nuclei, [10] that area unit airborne transmission usually thoughtabout to be particles $<5 \mu \mathrm{m}$ in diameter, will remain with in the air for long periods of your time and be transmitted to others over distances longer than one meter [11].

With regards to COVID - 19, the transmission system is additionally potential in explicit conditions and settings during which techniques or bolster medicines that produce pressurized canned products territory unit performed; i.e., manual ventilation before brooding, turning the patient to the inclined position, detaching the patient from the ventilator, non-obtrusive positive-pressure ventilation, careful activity, and heart resuscitation [6].

There is some proof that COVID - 19 infection could cause internal organ infection and be present in feces. However, up to now, just one study has civilized the COVID - 19 virus from one stool specimen [42]. There are no reports of fecal-oral transmission of the COVID - 19 virus up to now.

\section{Four Stages Of Global Pandemic}

As indicated by the report, the first stage is when instances of contamination are brought into a country that was not the source of the disease. At that moment, all the country outside of China that began announcing instances of coronavirus reached at Stage 1 of the outbreak as they revealed their first case of infection [8]. If a virus is contained after transmission to just one or two countries, it doesn't turn in to a pestilence, however on the off chance that it can't be contained during a limited period of time and spreads over the world, as COVID - 19 did, [41] it turns in to an epidemic [36].

The second stage of a pandemic is when there are instances of local transmission inside the country; the report clarifies [33]. This means the individual from whom the contamination spread to an alternate individual is from the same country. During this stage, the direction of the infection is generally recognized from the source to all the contaminated people [27].

Community transmission is the third stage of the pandemic, in this stage, predictable with the report; it turns out to be difficult to follow the chain of transmission of the infection in a sizable measure of cases. This recommends the infection has begun circling inside the network and may likewise contaminate those people who neither have headed out to a country experiencing the pandemic nor have come into the contact of an individual contaminated by the infection. During this event, [20] a lockdown turns out to be profoundly significant as an individual can spread the infection, paying little heed to their movement history or the individuals they need are accessible in contact with [34].

The fourth phase is when the virus infection gets endemic in certain continues reemerging around the year. This is frequently a phase that the Indian government has mulled over in its choice to handle the infection, the IE report states [39].

These stages of an episode stay uniform over the planet to shape coordination and understanding less difficult, all together that countries are frequently arranged in like manner. Such an order makes it simpler for different countries to force quantifiers that they think will profit, [24] like India forcing travel limitations on China very right on time inside the epidemic. This was on the grounds that, the report states, around then of your time all the instances of coronavirus in different nations were being imported from China [21].

\section{Management Of Patient}

The incubation time for coronavirus is said to be extended to 14 days, with in a time of 4-5 days from exposure to symptoms onset. One research study revealed that $97 \%$ of persons with con- 
firmed COVID - 19 develop symptoms can therefore at intervals of 11.5 days of coronavirus infection [19].

The signs and symptoms of novel corona virus present at unwellness onset vary, however over the course of the sickness, [44] most persons with COVID - 19 can have Fever, Cough, Anorexia, Fatigue, Sputum production, dyspnea, Myalgia and Atypical symptoms are mostly seen in older adults and persons with past medical history and comorbidities may have delayed presentation of fever and respiratory signs and symptoms. An article concluded, it is referenced around 1,000 hospitalized patients, fever was present in just $44 \%$ at hospital admission however later developed in $89 \%$ in the hospital [22]. Confusion, Headache, rhinorrhea, hemoptysis, pharyngitis, vomiting, and diarrhea symptoms are reported less frequent $(<10 \%)$ [37]. Dysnomia or ageusia preceding the onset of respiratory symptoms has been anecdotally reported, however additional info is required to grasp its role in characteristic COVID - 19 [3, 35].

\section{Infection Prevention and Control}

Immediate recognition, Securing triage, and preventing the source of infection. Clinical storage includes a system for assuring all patients at admission, allowing for early identification of possible COVID - 19 and immediate quarantine of patients with Suspected infection in an area isolated from other patients [38]. Standard precautionary measures include hand and respiratory cleanliness, the utilization of appropriate personal protective equipment (PPE) according to a risk assessment, waste management, environmental cleaning, conventional linens, and sterilization of patient-care supplies [1].

In addition to utilizing the standard precautions, all people, including family members and guests, should use contact and droplet precautionary measures before entering the room of suspected or Confirmed COVID -19 patient, Patient should be placed in inadequately ventilated single rooms. For a general wardroom with natural ventilation, sufficient Ventilation is considered [24].

$60 \mathrm{~L} / \mathrm{s}$ per patient. Authoritative controls and arrangements for the avoidance and control of transmission of COVID - 19 within the health care setting include, yet may not be constrained to building up practical IPC infrastructure and activities. Instructing patients developing policies on early recognition of acute respiratory infection potentially could by Could- 19 infections [37].

\section{Conclusion}

This study is a picture of current research of transmission, management, prevention, and pandemic of ongoing Coronavirus. protect yourself as well as other people around you by knowing the information and taking Appropriate measures, follow the suggestion given by your near by general wellbeing office.

\section{References}

[1]. Adhikari SP, Meng S, Wu YJ, Mao YP, Ye RX, Wang QZ, et al. Epidemiology, causes, clinical manifestation and diagnosis, prevention and control of coronavirus disease (COVID-19) during the early outbreak period: a scoping review. Infect Dis Poverty. 2020 Mar 17;9(1):29. Pubmed PMID: 32183901.

[2]. Almeida JD, Tyrrell DA. The morphology of three previously uncharacter- ized human respiratory viruses that grow in organ culture. J Gen Virol. 1967 Apr;1(2):175-8. Pubmed PMID: 4293939.

[3]. Balaji S, Brundha MP. Awareness of Breast Cancer among Dental Surgeons. Sciences and Research 2016.

[4]. Balasubramanian M. Covid 19-The new age pandemic. Notion Press; 2020 May 19.

[5]. Bande F, Arshad SS, Hair Bejo M, Moeini H, Omar AR. Progress and challenges toward the development of vaccines against avian infectious bronchitis. Journal of immunology research. 2015 Oct;2015.

[6]. Brundha MP. A Comparative Study-The Role of Skin and Nerve Biopsy in Hansen's Disease. Journal of Pharmaceutical Sciences and Research. 2015 Oct 1;7(10):837.

[7]. Ferdioz J, Brundha MP. Awareness of stye. International Journal of Pharmaceutical Sciences Review and Research. 2016 Jan 1;40(1):30-2.

[8]. Brundha MP, Nallaswamy D. Hide and seek in pathology-A research on game-based histopathology learning. International Journal of Research in Pharmaceutical Sciences. 2019 Apr 29;10(2):1410-4.

[9]. Brundha MP, Pathmashri VP, Sundari S. Quantitative changes of red blood cells in cancer patients under palliative radiotherapy-a retrospective study. Research Journal of Pharmacy and Technology. 2019 Feb 1;12(2):687-92.

[10]. Burke RM, Midgley CM, Dratch A, Fenstersheib M, Haupt T, Holshue M, et al. Active Monitoring of Persons Exposed to Patients with Confirmed COVID-19 - United States, January-February 2020. MMWR Morb Mortal Wkly Rep. 2020 Mar 6;69(9):245-246. Pubmed PMID: 32134909.

[11]. Chan JF, Yuan S, Kok KH, To KK, Chu H, Yang J, et al. A familial cluster of pneumonia associated with the 2019 novel coronavirus indicating personto-person transmission: a study of a family cluster. The lancet. $2020 \mathrm{Feb}$ 15;395(10223):514-23.

[12]. Chen N, Zhou M, Dong X, Qu J, Gong F, Han Y, et al. Epidemiological and clinical characteristics of 99 cases of 2019 novel coronavirus pneumonia in Wuhan, China: a descriptive study. Lancet. 2020 Feb 15;395(10223):507513. Pubmed PMID: 32007143.

[13]. Conly J, Thakur R, Eremin S, Silva CP. Field evaluation (FE) of the World Health Organization (WHO) interim guidelines (IG) on infection prevention and control (IPC) of epidemic and pandemic-prone acute respiratory diseases (ARD) in health care. In BMC proceedings 2011 Dec 5; (6):1-1.

[14]. Corman VM, Jores J, Meyer B, Younan M, Liljander A, Said MY, et al. Antibodies against MERS coronavirus in dromedary camels, Kenya, 1992-2013. Emerging infectious diseases. 2014 Aug;20(8):1319.

[15]. Cui J, Li F, Shi ZL. Origin and evolution of pathogenic coronaviruses. Nature Reviews Microbiology. 2019 Mar; 17(3):181-92.

[16]. Decaro N. Alphacoronavirusł: Coronaviridae. The Springer Index of Viruses. 2011:371.

[17]. Estola T. Coronaviruses, a new group of animal RNA viruses. Avian Dis. 1970 May;14(2):330-6. Pubmed PMID: 4316767.

[18]. Fabricant J. The early history of infectious bronchitis. Avian Dis. 1998 OctDec;42(4):648-50. Pubmed PMID: 9876830.

[19]. Guan WJ, Ni ZY, Hu Y, Liang WH, Ou CQ, He JX, et al. Clinical characteristics of coronavirus disease 2019 in China. New England journal of medicine. 2020 Apr 30;382(18):1708-20.

[20]. Hannah R, Ramani P, Brundha MP, Sherlin HJ, Ranjith G, Ramasubramanian A, et al. Liquid paraffin as a rehydrant for air dried buccal smear. Research Journal of Pharmacy and Technology. 2019 Mar 1;12(3):1197-200.

[21]. Harsha L, Brundha MP. Prevalence of dental developmental anomalies among men and women and its psychological effect in a given population. Journal of Pharmaceutical Sciences and Research. 2017 Jun 1;9(6):869.

[22]. Huang C, Wang Y, Li X, Ren L, Zhao J, Hu Y, et al. Clinical features of patients infected with 2019 novel coronavirus in Wuhan, China. The lancet. $2020 \mathrm{Feb} 15 ; 395(10223): 497-506$.

[23]. Kahn JS, McIntosh K. History and recent advances in coronavirus discovery. The Pediatric infectious disease journal. 2005 Nov 1;24(11):S223-7.

[24]. Kalaiselvi R, Brundha MP. Prevalence of hysterectomy in South Indian population. Research Journal of Pharmacy and Technology. 2016;9(11):1941-4.

[25]. Kapikian AZ, James HD Jr, Kelly SJ, Dees JH, Turner HC, McIntosh K, et al. Isolation from man of "avian infectious bronchitis virus-like" viruses (coronaviruses) similar to 229E virus, with some epidemiological observations. J Infect Dis. 1969 Mar;119(3):282-90. Pubmed PMID: 4976345.

[26]. Kendall EJ, Bynoe ML, Tyrrell DA. Virus isolations from common colds occurring in a residential school. British medical journal. $1962 \mathrm{Jul}$ 14;2(5297):82.

[27]. Kumar MA, Brundha MP. Awareness about nocturia-A questionnaire survey. Research Journal of Pharmacy and Technology. 2016 Oct 1;9(10):1707.

[28]. Li B, Yang J, Zhao F, Zhi L, Wang X, Liu L, Bi Z, Zhao Y. Prevalence and impact of cardiovascular metabolic diseases on COVID-19 in China. Clin Res Cardiol. 2020 May;109(5):531-538. Pubmed PMID: 32161990.

[29]. Liu J, Liao X, Qian S, Yuan J, Wang F, Liu Y, et al. Community Transmission of Severe Acute Respiratory Syndrome Coronavirus 2, Shenzhen, Chi- 
na, 2020. Emerg Infect Dis. 2020 Jun;26(6):1320-1323. Pubmed PMID: 32125269

[30]. Lai MM, Cavanagh D. The molecular biology of coronaviruses. Advances in virus research. 1997 Jan 1;48:1-00.

[31]. McIntosh K. Coronaviruses: a comparative review. Current topics in microbiology and immunology/Ergebnisse der Mikrobiologie und Immunitätsforschung. 1974:85-129.

[32]. Ong SW, Tan YK, Chia PY, Lee TH, Ng OT, Wong MS, et al. Air, surface environmental, and personal protective equipment contamination by severe acute respiratory syndrome coronavirus 2 (SARS-CoV-2) from a symptomatic patient. Jama. 2020 Apr 28;323(16):1610-2.

[33]. Prashaanthi N, Brundha MP. A comparative study between popplet notes and conventional notes for learning pathology. Research Journal of Pharmacy and Technology. 2018;11(1):175-8.

[34]. Preethikaa S, Brundha MP. Awareness of diabetes mellitus among general population. Research Journal of Pharmacy and Technology. 2018 May 30;11(5):1825-9

[35]. Ravichandran H, Brundha MP. Awareness about personal protective equipments in hospital workers (sweepers and cleaners). International Journal of Pharmaceutical Sciences Review and Research. 2016;40(1):28-9.

[36]. Saif F. COVID-19 pandemic in Pakistan: stages and recommendations. medRxiv. 2020 Jan 1.

[37]. Shen K, Yang Y, Wang T, Zhao D, Jiang Y, Jin R, et al. China National Clinical Research Center for Respiratory Diseases; National Center for Children's Health, Beijing, China; Group of Respirology, Chinese Pediatric Society, Chinese Medical Association; Chinese Medical Doctor Association Committee on Respirology Pediatrics; China Medicine Education Association Committee on Pediatrics; Chinese Research Hospital Association Committee on Pediatrics; Chinese Non-government Medical Institutions Association Committee on Pediatrics; China Association of Traditional Chinese Medicine, Committee on Children's Health and Medicine Research; China News of Drug Information Association, Committee on Children's Safety Medi- cation; Global Pediatric Pulmonology Alliance. Diagnosis, treatment, and prevention of 2019 novel coronavirus infection in children: experts' consensus statement. World J Pediatr. 2020 Jun;16(3):223-231. Pubmed PMID: 32034659 .

[38]. Shenoy PB, Brundha MP. Awareness of polycystic ovarian disease among females of age group 18-30 years. Journal of Pharmaceutical Sciences and Research. 2016 Aug 1;8(8):813.

[39]. Shreya S, Brundha MP. Alteration of haemoglobin value in relation to age, sex and dental diseases-A retrospective correlation study. Research Journal of Pharmacy and Technology. 2017 May 1;10(5):1363.

[40]. Su S, Wong G, Shi W, Liu J, Lai ACK, Zhou J, et al. Epidemiology, Genetic Recombination, and Pathogenesis of Coronaviruses. Trends Microbiol. 2016 Jun;24(6):490-502. Pubmed PMID: 27012512.

[41]. Timothy CN, Samyuktha PS, Brundha MP. Dental pulp Stem Cells in Regenerative Medicine-A Literature Review. Research Journal of Pharmacy and Technology. 2019 Aug 1;12(8):4052-6.

[42]. Wang D, Hu B, Hu C, Zhu F, Liu X, Zhang J, et al. Clinical characteristics of 138 hospitalized patients with 2019 novel coronavirus-infected pneumonia in Wuhan, China. Jama. 2020 Mar 17;323(11):1061-9.

[43]. Woo PC, Lau SK, Chu CM, Chan KH, Tsoi HW, Huang Y, et al. Characterization and complete genome sequence of a novel coronavirus, coronavirus HKU1, from patients with pneumonia. J Virol. 2005 Jan;79(2):884-95. Pubmed PMID: 15613317.

[44]. Zhang Y, Chen C, Zhu S, Shu C, Wang D, Song J, et al. Isolation of 2019$\mathrm{nCoV}$ from a stool specimen of a laboratory-confirmed case of the coronavirus disease 2019 (COVID-19). China CDC Weekly. 2020 Feb 1;2(8):123-4.

[45]. Zhu N, Zhang D, Wang W, Li X, Yang B, Song J, et al. China Novel Coronavirus Investigating and Research Team. A Novel Coronavirus from Patients with Pneumonia in China, 2019. N Engl J Med. 2020 Feb 20;382(8):727733. Pubmed PMID: 31978945. 